\title{
In vitro antagonism of Phytophthora capsici and Fusarium solani by bacterial isolates from Sarawak
}

\author{
Mohd Farith Kota*, Awang Ahmad Sallehin Awang Husaini, Samuel Lihan, Mohd Hasnain Md. Hussain \\ and Hairul Azman Roslan
}

Department of Molecular Biology, Faculty of Resource Science and Technology,

Universiti Malaysia Sarawak, 94300 Kota Samarahan, Sarawak, Malaysia.

*Email: farith@live.com.my

\begin{abstract}
Aims: Phytophthora capsici and Fusarium solani are common fungal pathogens causing severe diseases that lead to economic loss in pepper industry, especially in Sarawak. In response to the infections, chemical approach is more common; nevertheless, biological control is more favorable to control fungal pathogens. Biological control approach greatly reduces the problems associated with chemical applications and it restores balance of the natural environment. Here we present the ongoing work to study the action of antagonistic bacteria, Bacillus sp. and Pseudomonas sp., that produce volatile and non-volatile antifungal compounds against $P$. capsici and $F$. solani on pepper plants.

Methodology and results: A total of seven bacterial candidates were isolated from different locations and tested for their antagonistic properties against $P$. capsici and $F$. solani in a dual culture assay and extracellular metabolite test. Extracellular hydrolytic enzymes production was also monitored and followed by genotypic indentification. Preliminary antagonism tests indicated that bacterial isolate Pep3 and Pep4 inhibit up to $50 \%$ of the growth of $P$. capsici and $F$. solani as compared to the control. Subsequent investigation on extracellular hydrolytic enzyme production revealed that both bacterial isolates are capable of secreting hydrolytic enzymes. Microscopic and genotypic analyses identified the bacterial isolates Pep3 as Bacillus amyloliquefaciens (KJ461444) and Pep4 as Pseudomonas pachastrellae (KM460937).

Conclusion, significance and impact of study: B. Amyloliquefaciens (KJ461444) and P. pachastrellae (KM460937) inhibited the growth of $P$. capsici and $F$. solani thus reflecting the potential of the produced metabolites to be purified and used in combating plant pathogenic fungi.
\end{abstract}

Keywords: antagonism, Fusarium solani, Phytophthora capsici

\section{INTRODUCTION}

Piper nigrum, or generally known as pepper, is one of the major export products from Sarawak and mainly used as a spice and flavoring ingredient in food. According to the report published by the State Planning Unit, Chief Minister's Department of Sarawak, a total of 24, 000 tonnes of pepper (white and black) was produced from 14,000 hectares of planted area. Even with the large pepper production, the pepper plantations/farmers are continuously faced with the threat of infections from pathogens. Phytophthora capsici and Fusarium solani are common fungal pathogens that cause severe infections leading to economic loss in the pepper industry. Infection by $P$. capsici in the nursery may result in either wilting of the pepper cuttings or rotting of tender leaves, and $F$. solani causes yellow disease on pepper. To control these pathogens, farmers opted for chemical based fungicides as they are effective despite of the high price. Continuous application of chemical products and improper disposal of them has become a threat to human health. Biological control methods have emerged as an important alternative in managing soil borne plant diseases in recent years with the added advantage of being more environmental friendly. Therefore, this research was initiated to identify and characterize suitable biological control agent/s to be used in controlling pathogenic fungus.

\section{MATERIALS AND METHODS}

\section{Preparation of inoculums}

Plant pathogenic fungi, $P$. capsici and $F$. solani, were obtained from Malaysian Pepper Board (MPB) and maintained on malt extract agar (MEA) plates at $28^{\circ} \mathrm{C}$ for 7 days before being used as the working culture. Seven unidentified bacterial cultures, coded Pep1 to Pep7, isolated from various sources including soil and seawater, were used in this experiment. Working stock of each bacterial culture was prepared prior to usage by overnight incubation in Luria Bertani broth at $37^{\circ} \mathrm{C}$. 


\section{Primary selection of antagonists}

Bacterial isolates were tested against $P$. capsici and $F$. solani using dual culture assay (Ann, 2012) and extracellular metabolite efficacy test (Tariq et al., 2010). For dual culture assay, $1 \mathrm{~cm}^{2}$ mycelia plug of the pathogenic fungus was placed at the center of a Petri dish containing MEA and grown together with the bacteria that were placed surrounding the fungal inoculum in a $5 \mathrm{~cm}$ diameter. Plates were cultured for 7 days at $28^{\circ} \mathrm{C}$ and the growth diameter of the pathogen (fungal growth) was measured and compared to the control (bacterial suspension was replaced by sterile distilled water). Each experiment uses a single pathogen isolate and was conducted in triplicate. The results obtained are expressed as means of percentages of inhibition together with the standard deviations of the growth of the corresponding pathogen isolate in the presence of bacterial isolates. Percentage of inhibition was calculated using the following formula:

Percentage of inhibition $=$

[1 - (Fungal growth / Control growth) $\times 100$

The extracellular metabolite efficacy test was performed by placing a filter sterilized bacterial supernatant into MEA and $1 \mathrm{~cm}^{2}$ mycelia plug of the pathogenic fungus was placed at the center of the Petri dish. Plates were cultured for 7 days at $28{ }^{\circ} \mathrm{C}$ and growth diameter of the pathogen (fungal growth) was measured and compared to the control. Each experiment used a single pathogen isolate and conducted in triplicate. Percentage of inhibition was calculated using the formula as above (1).

\section{Mechanisms involved in antagonism}

Volatile antibiotic production was analyzed based on a method described by Ann (2012). The bacterial culture was grown in sterile LB broth at $37^{\circ} \mathrm{C}$ for $24 \mathrm{~h}$. A total of $100 \mu \mathrm{L}$ bacterial suspension was placed at the center of the Petri dish containing Nutrient Agar (NA) and aseptically spread using spreading technique. Another Petri dish containing MEA was inoculated with a $1 \mathrm{~cm}^{2}$ mycelia plug of pathogenic fungus which was placed at the center of the Petri dish. Both plates were placed face to face without any physical contact between the pathogen and the bacterial culture. Plates were sealed to isolate the inside atmosphere and to prevent loss of volatiles formed. Plates were cultured for 7 days at $28{ }^{\circ} \mathrm{C}$ and radial growth of the pathogen was measured and compared to the control where the bacterial suspension was replaced by sterile distilled water. The experiment was conducted in triplicate. Percentage of inhibition was calculated using the formula as described in the previous section.

Production of non-volatile antibiotics was detected using MEA plates, covered with a cellulose membrane and inoculated with $100 \mu \mathrm{L}$ of bioantagonistic bacterial suspension grown overnight. After an overnight incubation at $37^{\circ} \mathrm{C}$, the membrane with grown bacterial isolate was removed and the plate was inoculated with a $1 \mathrm{~cm}^{2}$ mycelia plug of pure culture of the pathogenic fungus. Plates were incubated at $28{ }^{\circ} \mathrm{C}$ for 7 days. Controls were run with bacterial suspension replaced by sterile distilled water, and further inoculated with pathogenic fungus. Each experiment used a single pathogen isolate and was conducted in triplicates. Percentage of inhibition was calculated using formula (1).

\section{Hydrolytic enzyme detection}

Chitinase, protease and cellulase were detected based on halo formation of agar plates after inoculation of bacterial isolates. For chitinase detection, colloidal chitin suspension was prepared according to the method described by Mathur et al. (2011). Ten grams of chitin was ground in a mortar and pestle for $5 \mathrm{~min}$ and slowly dissolved in $400 \mathrm{~mL}$ of concentrated $\mathrm{HCl}$ with stirring at 4 ${ }^{\circ} \mathrm{C}$. To this mixture, four liters of sterile distilled water was added and left overnight at $4{ }^{\circ} \mathrm{C}$. The supernatant was slowly decanted, the precipitate was collected on a filter paper and washed extensively with sterile distilled water to attain neutral $\mathrm{pH}$. The colloidal chitin was dissolved in $250 \mathrm{~mL}$ sterile distilled water and stored at $4{ }^{\circ} \mathrm{C}$ prior to use. Chitinase detection agar plate was prepared by mixing $10 \mathrm{~g}$ of colloidal chitin and $20 \mathrm{~g}$ of agar in medium containing salts [(unit of salts $\mathrm{g} / \mathrm{L}$ ): $\mathrm{Na}_{2} \mathrm{HPO}_{4}, 0.65$; $\mathrm{KH}_{2} \mathrm{PO}_{4}, 1.5 ; \mathrm{NaCl}, 0.25 ; \mathrm{NH}_{4} \mathrm{Cl}, 0.5, \mathrm{MgSO}_{4}, 0.12$; and $\mathrm{CaCl}_{2}, 0.005$ ]. The final $\mathrm{pH}$ was adjusted to 6.5 (Usharani and Gowda, 2011).

Protease production was tested by inoculating each bacterial isolate on Skim Milk Agar (SMA) on the petri plates. Agar plates were incubated overnight at $37^{\circ} \mathrm{C}$. The bacterial isolates that produced protease were identified by halo zones around the bacterial colony and were observed (Katekan, et. al., 2009). Cellulase production was tested by inoculating each bacterial isolate on Minimal Salt Agar (MSA) containing $1 \%$ of carboxymethyl cellulose, as sole carbon source and substrate. The Minimal Salt Agar (MSA) composed of (g/L): $\mathrm{NA}_{2} \mathrm{HPO}_{4}, 6 ; \mathrm{K}_{2} \mathrm{SO}_{4}, 0.2 ; \mathrm{NH}_{4} \mathrm{NO}_{3}, 4 ; \mathrm{KH}_{2} \mathrm{SO}_{4}, 4$; $\mathrm{MgSO}_{4} \cdot 7 \mathrm{H}_{2} \mathrm{O}, 0.2 ; \mathrm{CaCl}_{2} \cdot 2 \mathrm{H}_{2} \mathrm{O}, 0.01 ; \mathrm{FeSO}_{4} \cdot 7 \mathrm{H}_{2} \mathrm{O}, 0.01$; and agar, 15 in $1 \mathrm{~L}$ of water. Agar plates were incubated overnight at $37{ }^{\circ} \mathrm{C}$. After incubation, the plates were flooded with $1 \%$ Congo red solution for 30 min before being washed with sterile distilled water. The bacterial isolates that produced cellulase were identified by halo zone around the bacterial colony and were observed (Kasana et. al., 2008).

\section{Extraction of volatile compounds}

To detect volatile compounds, $100 \mathrm{~mL}$ bacterial culture filtrates were extracted four times using three different organic solvents: diethyl ether (Extract $E$ ), mixture of pentane/diethyl ether $(1: 1, \mathrm{v} / \mathrm{v})($ Extract $P / E)$, and mixture of pentane/dichloromethane $(2: 1, \mathrm{v} / \mathrm{v})($ Extract P/D) (Liu et al., 2008). After extraction, the upper organic phase wasseparated, it was dried over anhydrous sodium sulphate and concentrated using rotary evaporator. The 
extracts were then stored at $-20{ }^{\circ} \mathrm{C}$ prior to GC-MS analysis. All extractions were performed in triplicate.

\section{Gas Chromatography-Mass Spectrometry (GC-MS) analysis}

Compounds were identified by GC-MS using a Shimadzu GCMS-QP2010 Plus (Shimadzu Corp. Japan) equipped with a BPX5 capillary column. Helium (flow rate, 1.0 $\mathrm{ml} / \mathrm{min}$ ) was used as the carrier gas, and injection volumes were $1 \mu \mathrm{L}$. The column temperature was maintained at $40{ }^{\circ} \mathrm{C}$ for $3.5 \mathrm{~min}$, followed by increases to $60{ }^{\circ} \mathrm{C}$ at a rate of $5^{\circ} \mathrm{C} / \mathrm{min}$, from 60 to $120^{\circ} \mathrm{C}$ at a rate of $6{ }^{\circ} \mathrm{C} / \mathrm{min}$, and from 120 to $230{ }^{\circ} \mathrm{C}$ at a rate of $8{ }^{\circ} \mathrm{C} / \mathrm{min}$. Finally at $230{ }^{\circ} \mathrm{C}$ the temperature was held constant for 12 min. The electron impact energy was $70 \mathrm{eV}$ and the ion source temperature was set at $230^{\circ} \mathrm{C}$. Electron impact (EI) mass spectra were recorded in the 33 to $450 \mathrm{aMU}$ range at $1 \mathrm{~s}$ interval (Liu et al., 2008).

\section{Molecular identification of bacterial isolates}

Total genomic DNA was purified from overnight grown LB culture by using the Wizard genomic DNA purification kit (Promega Inc., Madison, WI, USA). To identify the isolates, PCR amplification and sequencing of the $16 \mathrm{~S}$ rRNA gene were performed.The 16S rRNA genes were PCR-amplified from the genomic DNA using the bacterial universal primer set of pA (5'-AGA GTT TGA TCC TGG CTC AG-3') and pH (5'-GGC TAC CTT GTT ACG ACT T$\left.3^{\prime}\right)$. The PCR reaction mixture consisted of $2.5 \mu \mathrm{L}$ of $10 \times$ PCR reaction buffer $(20 \mathrm{mM}$ Tris $-\mathrm{HCl} \mathrm{pH} 8.0,100 \mathrm{mM}$ $\mathrm{KCl}, 0.5 \%$ Tween 20, 0.5\% Igepal CA-630, $0.1 \mathrm{mM}$ EDTA, $1 \mathrm{mM}$ dithiothretiol and $50 \%$ glycerol), $1 \mu \mathrm{L}$ of $10 \mathrm{mM}$ dNTP mix, $1 \mu \mathrm{L}$ of $10 \mathrm{pM}$ primers, $3.0 \mu \mathrm{L}$ of genomic DNA template, $2.0 \mu \mathrm{L}$ of $\mathrm{MgCl}_{2}$ and $0.5 \mu \mathrm{L}$ Taq DNA Polymerase (EURx) prepared in a final $25 \mu \mathrm{L}$ reaction volume. Amplification was carried out with the BioRad iCycler PCR Thermal Cycler. The thermal cycling program was as follows: initial denaturation at $96{ }^{\circ} \mathrm{C}$ for $5 \mathrm{~min}$, which was followed by 30 cycles of denaturation at $96{ }^{\circ} \mathrm{C}$ for $30 \mathrm{sec}$, primer annealing at $55^{\circ} \mathrm{C}$ for $1 \mathrm{~min}$, extension at $72{ }^{\circ} \mathrm{C}$ for $1 \mathrm{~min}$, and a final extension at $72{ }^{\circ} \mathrm{C}$ for $7 \mathrm{~min}$. The amplified PCR products were analyzed on $1.0 \%(\mathrm{w} / \mathrm{v})$ agarose gel. The size of the amplified DNA was estimatedby comparingwith $1 \mathrm{~kb}$ DNA ladder. Elution of the amplified DNA fragment and sequencing was performed using the services by First BASE Laboratories Sdn Bhd, Malaysia. The 16S rRNA gene sequences were then compared with those in NCBI GenBank database (http://www.ncbi.nlm.nih.gov/genbank) using the BLASTN program and strains that were closely related were aligned using the CLUSTAL W program.

\section{Phylogenetic analysis}

The sequences were searched for sequence homology in GenBank NCBI-BLAST with the 16S rDNA sequences, and were identified to the genera level. Using the CLUSTAL-W Multiple Sequence Alignment Program
(Strasburg, France), the 16S rDNA sequences of the isolated strains were aligned with sequences of related organisms obtained from GenBank. Phylogenetic analysis was performed with MEGA 5.0 (Tamura et al., 2011), and a phylogenetic tree was constructed via the neighborjoining method (Saito and Nei, 1987) using the the same program. To validate the reproducibility of the branching pattern, a bootstrap analysis was performed.
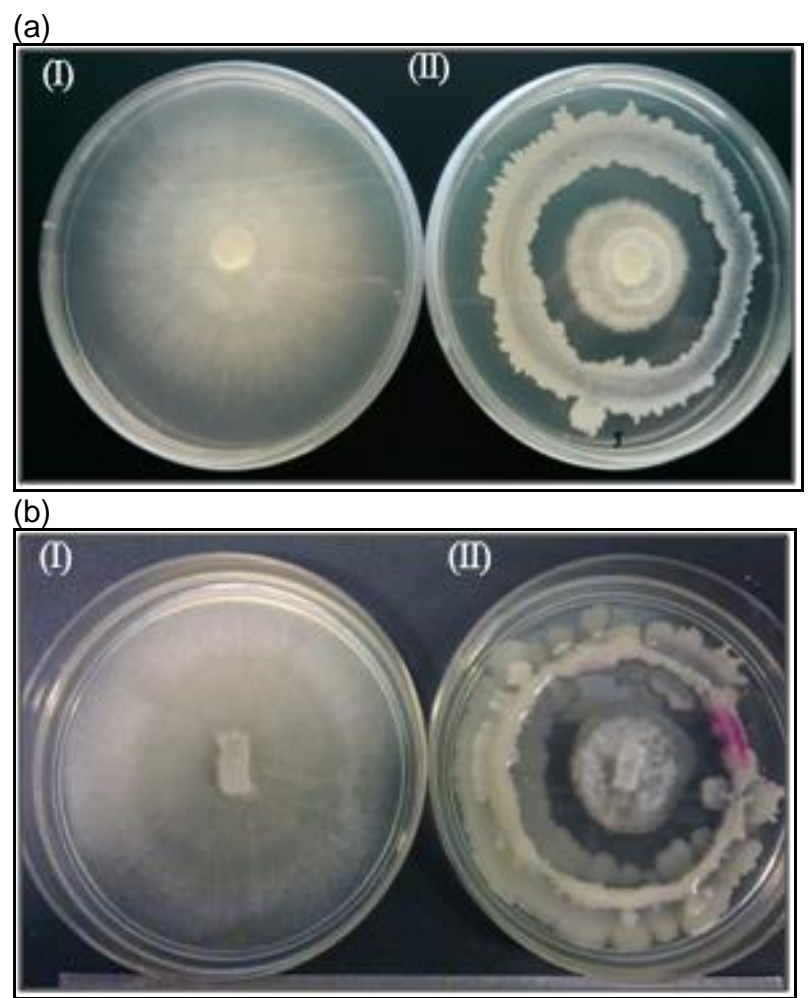

Figure 1: Analysis of dual culture assay. MEA agar plate that was inoculated with (a) (I) P.capsici and sterile distilled water; (II) P.capsici and bacterial isolate Pep3; (b) (I) F. solani andsterile distilled water; (II) F. solani and bacterial isolate Pep4.

\section{RESULTS AND DISCUSSION}

Development of an in vitro screening system that provides repeatable and reliable results in a shorter period of time is an important initial step in the isolation of beneficial bacterial antagonists for plant disease management. The work utilizes a dual culture assay to quickly identify antagonistic bacteria, Pep3 and Pep4. The isolated bacteria inhibited $50 \%$ of the growth of $P$. capsici (Pep3) and $F$. solani (Pep4) (Figure 1). An inhibitory halo was observed and produced by Pep3 and Pep4 indicating secretion of fungistatic metabolites by the bacterial isolates (Montealegre et al., 2003). The fungistatic metabolites can be grouped into volatile and non-volatile compounds (Chang-Song et al., 2007). 
(a)

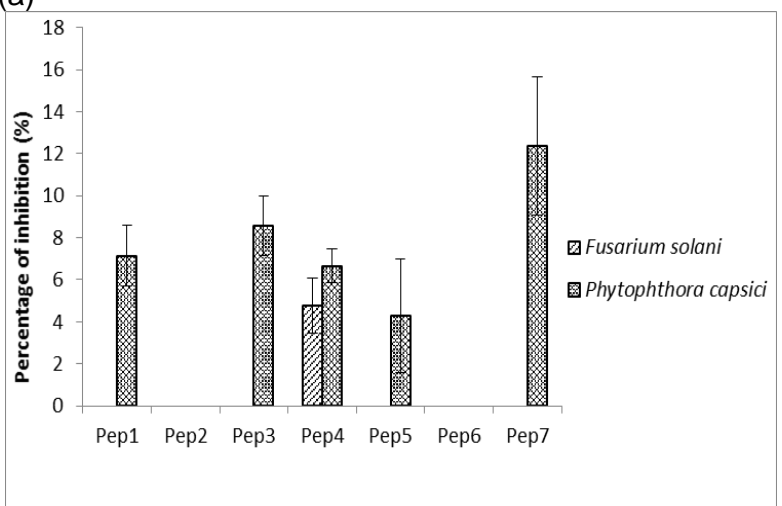

(b)

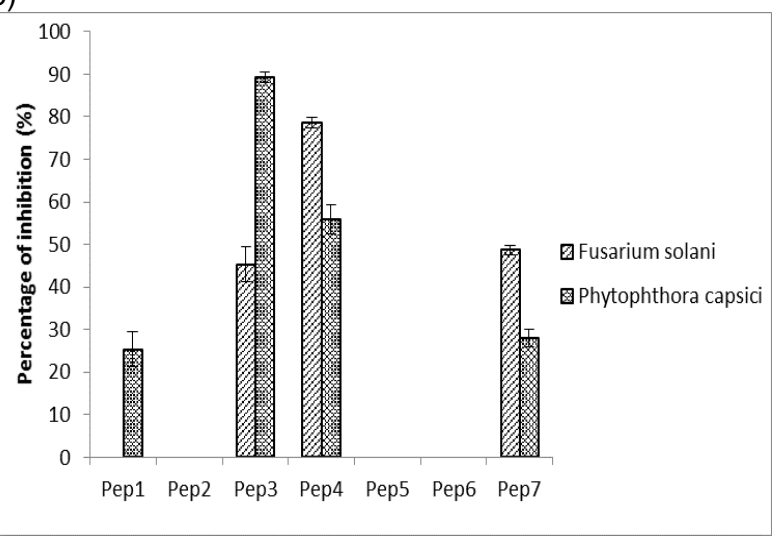

Figure 2: Percentage of inhibition of antagonistic bacteria isolates (Pep1-Pep7). The isolates were challenged against Phytophthora capsici and Fusarium solani via volatile (a) and diffusible antibiotic tests (b).

Dual assay culture and extracellular metabolites efficacy tests showed that the bacterial isolates inhibited the growth of pathogenic fungi. Two assays, volatile antibiotics test and diffusible antibiotic test, were conducted to shed light on the possible modes of action involved in the inhibition. Results from volatile antibiotic tests showed that the growth of pathogenic fungus was significantly inhibited by the isolates at a lower percentage of inhibition (Figure 2a). Low percentage of inhibition suggested that the bacterial isolate produce lower amount of volatile compound(s) responsible for the inhibition of fungal growth. However, higher percentage of inhibition was recorded through the diffusible antibiotic test, where isolate Pep3 inhibits the growth of $P$. capsici up to $90 \%$ and isolate Pep4 inhibits $80 \%$ of the growth of $F$. solani (Figure 2b). These results suggested that the main mechanism by bacteria involved in the antagonism was the production of diffusible metabolites with antibiotics or antifungal properties. This antifungal activity could be attributed to the production of extracellular hydrolytic enzymes such as chitinase, protease and/or cellulase (Elshafie et al., 2012).
Detection of hydrolytic-enzyme producing bacteria from natural sources such as soil is useful in the isolation of antagonists. A high correlation between chitinolysis and production of bioactive compounds has been reported which are responsible in bioantagonism (Jain and Jain, 2007; Hamdali et al., 2008). In the present study, hydrolytic enzymes secreted by the bacterial isolates were evaluated based on halo zone formation on agar (Figure 3). Pep3 isolate was found to secrete chitinases,

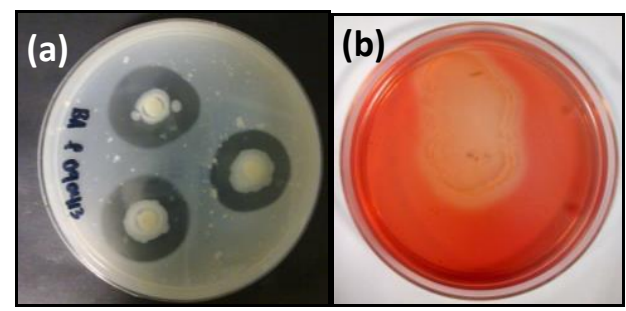

Figure 3: Analysis of proteases and cellulases produced by bacteria isolates. Halo zones produced by Pep3 isolate in (a) Skim Milk Agar (SMA); and (b) minimal salt agar (MSA) containing 1\% carboxymethylcellulose (CMC). Results for Pep4 isolate are not shown.

proteases and cellulases. However, the amount of chitinases secreted was low as compared to cellulases while the production of proteases is the highest. However for Pep4 isolate, only cellulase activity was detected. Microorganisms that secrete a complex of mycolytic enzymes are considered to have the potential to be biological control agents towards agents of infections (Hoster et al., 2005). Chitinases secreted by bacteria mainly degrade chitinand utilize it as an energy source since chitin is the most abundant renewable resource after cellulose. Bacteria capable of producing chitinases are potential agents to biologically control plant diseases caused by various phytopathogenic fungi. This is due to the ability of chitinases to inhibit fungal growth by hydrolyzing the chitin present in the fungal cell wall. Besides chitinase, the release of cellulase is also another mechanism responsible for antagonism in all the bacteria isolated. The enzymes are used by bacteria to degrate the cellulose within the cell walls of pathogens (Brantlee et al., 2011). Protease and cellulase production by bacteria may have provided amajor advantage in inhibiting the growth of $P$. capsici since their cell wall contains primarily of cellulose and protein,and a small amount of chitin (Meijer et al., 2006).

Previous studies reportedby Weiwei et al. (2008), Alstrom (2001) and Wheatley (2002), demonstrated that volatile organic compounds (VOCs) produced by bacteria can inhibit the growth of fungi. These VOCs include hydrocarbons, alcohols, ketones, aldehydes, ethers, esters, terpenes, terpene derivatives, and several heteroaromatic compounds. In our study, we observed clear differences in the organic components extracted from Pep3 and Pep4 culture fluids using three different solvent systems. Post run analysis using GC-MS revealed that these organic extracts, consisted of esters, alcohols, 
acids, hydrocarbons and heterocyclic compounds. The most significant component detected that correspond to antifungal effect was hexanedioic acid or generally known as adipic acid (Figure 4). Adipic acid has been reported to be capable of inhibiting in vitro mycelial growth and conidial germination (Flors et al., 2004). Another study conducted by Vicedo et al. (2006), reported that adipic acid effectively controlled phytopathogen Botrytis cinerea by preventing germ tube development which stop the spore germination process.

Molecular identification of the bacterial isolates was carried out based on 16S rDNA sequence analysis. Approximately $1.5 \mathrm{~kb}$ sequence was obtained from amplification of the genomic DNA of the bacterial isolates. The sequence was aligned with all available $16 \mathrm{~S}$ rDNA sequences in the NCBI GenBank database. From the sequence homology search, the bacterial isolates were identified as Bacillus amyloliquefaciens for isolate Pep3 and Pseudomonas pachastrellae for isolate Pep4. The partial 16S rDNA sequences were deposited into GenBank under accession number of KJ461444 (Pep3) and KM460937 (Pep4). A phylogenetic tree was constructed from the DNA sequence using neighborjoining method which showed that the bacterial isolates were identified correctly (Figure 5).

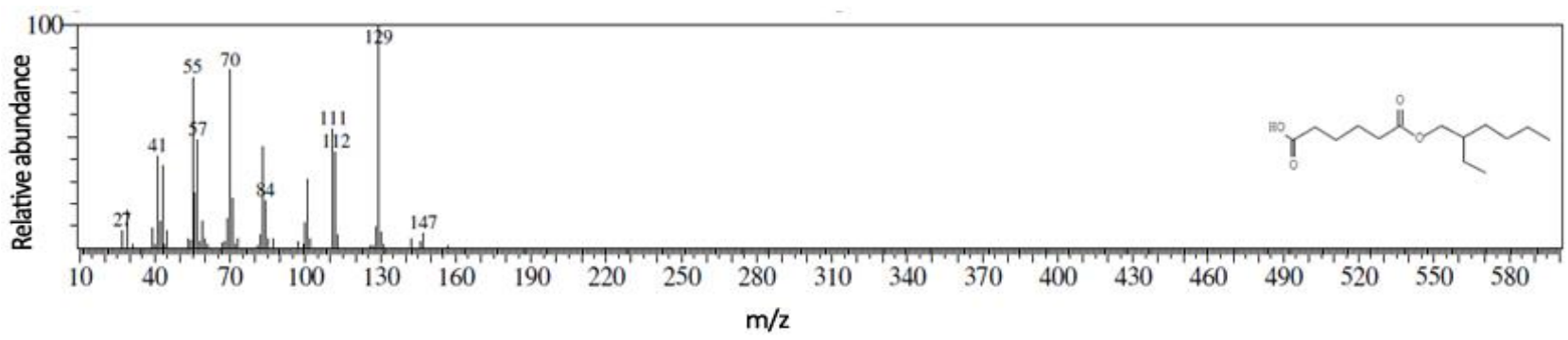

Figure 4: GC/MS mass spectrum profile and the structural formula of hexanedioic acid produced by bacterial isolate Pep3 and Pep4.

The ability of bacteria species from the genus Bacillus and Pseudomonas as biocontrol agent has been reported by others (Yu-Hong et al., 2010; Karimi et al., 2012; Vanitha and Ramjegathesh, 2014).Some Bacillus species such as B. amyloliquefaciens, B. subtilis, B. licheniformis, and $B$. cereus are known to inhibit the development of fungal plant pathogens by producing a variety of antibiotics. Three of the known groups of cyclic lipopeptides, surfactins, inturins and fengicins, possess amphipathic characters that are responsible for inhibiting the growth of fungi (Kim and Chung, 2004; Souto et al., 2004; Nogórska et al., 2007).Currently, there are many Pseudomonas based products such as FrostBan, BlightBan A506, BioSave $10 \mathrm{LP}$ and Bio-Save $11 \mathrm{LP}$ to name a few with moderate to excellent efficacy that are used in the farm to control plant diseases (Stockwell and Stack, 2007). Management of biological control agents in the field has been aided with the advancement of genomic analysis of these bacterial groups. The utilizationof such strains with beneficial properties is vital in agriculture as these bacteria are best adapted to conditions.

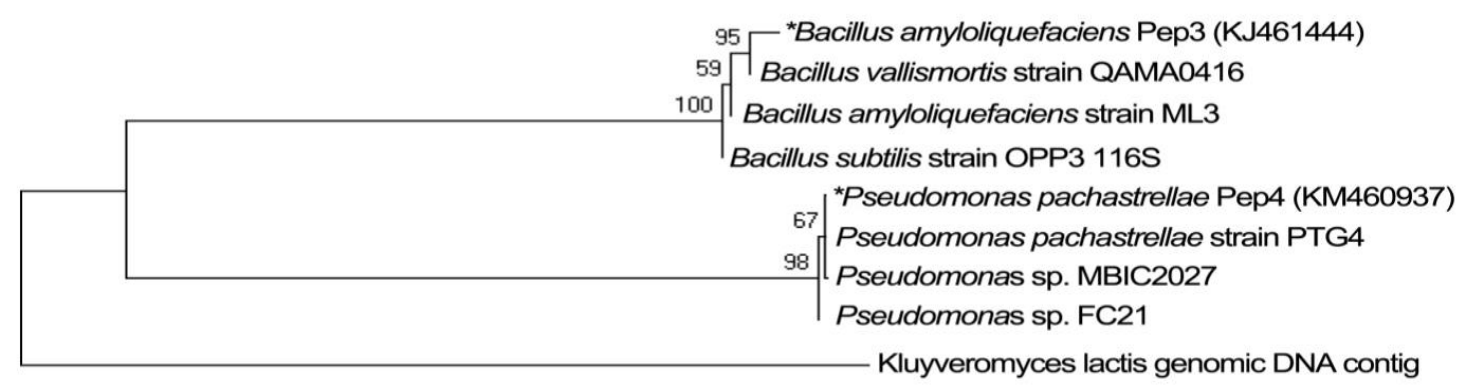

$\stackrel{\mapsto}{0.1}$

Figure 5: Phylogenetic tree based on partial 16S rDNA sequences. A tree was generated showing the relationship between the isolated strains and other species that belong to the genus Bacillus and Pseudomonas. An outgroup, Kluyvermyces lactis, was included to root the tree. The tree was constructed using the MEGA 5.0 and neighbour-joining method. Scale bar corresponds to 0.1 substitution per nucleotide position. Asterisk $\left({ }^{*}\right)$ indicates for isolates described in this report. 


\section{CONCLUSION}

We have isolated several bacteria with antagonistic properties with potential as biological control of $P$. capsici and $F$. solani. Further analysis of the bacteria $B$. amyloliquefacines and $P$. pachastrellae showed that they produce extracellular hydrolytic enzymes and metabolites that are diffusible and volatile. Synergistic action of these organic compounds is suspected to be involved in the antagonism effect on the growth of the pathogenic fungi. The preliminary results of this study suggested both isolates have the potential as biocontrol agents against the pathogenic fungi and thus, further investigation isneeded,such as chemical and biological characterization of the bioactive metabolites produced.

\section{ACKNOWLEDGEMENT}

This research project is funded by Ministry of Education Malaysia (MoE) under the Exploratory Research Grant Scheme (ERGS), ERGS/01(02)/852/2012(4). The authors would also like to thank Universiti Malaysia Sarawak and the Faculty of Resource Science and Technology for providing the research facilities and Malaysia Pepper Board for the fungal materials.

\section{REFERENCES}

Alstrom, S. (2001). Characteristics of bacteria from oil seed rape in relation to their biocontrol of activity against Verticillium dahliae. Journal of Phytopathology 149, 57-64.

Ann, Y. C. (2012). Rhizobacteria of pepper (Piper nigrum) and their antifungal activities. African Journal of Microbiology Research 6(19), 4185-4193.

Brantlee, S. R., Kelly, L., Wei, S. and Benson, D. M. (2011). Cellulase activity as a mechanism for suppression of phytophthora root rot in mulches. Phytopathology 101(2), 223-230.

Chang-Song, Z., Ming-He, M., Ying-Qi, G., Jun-Pei, Z. and Ke-Qin, Z. (2007). Possible contributions of volatile-producing bacteria to soil fungistasis. Soil Biology and Biochemistry 39, 2371-2379.

Elshafie, H. S., Camele, I., Racioppi, R., Scrano, L., lacobellis, N. S. and Bufo, S. (2012). In vitro antifungal activity of Burkholderia gladioli pv. agaricicola against some phytopathogenic fungi. International Journal of Molecular Sciences 13(12), 16291-16302.

Flors, V., Miralles, M. C., Varas, E., Company, P., Gonzalez-Bosch, C. and Garcıa-Agustın, P. (2004). Effect of analogues of plant growth regulators on in vitro growth of eukaryotic plant pathogens. Plant Pathology 53, 58-64.

Hamdali, H., Hafidi, M., Virolle, M. J. and Ouhdouch, Y. (2008). Rock phosphatesolubilizing Actinomycetes: Screening for plant growth-promoting activities. World Journal of Microbiology and Biotechnology 24, 25652575.
Hoster, F., Schmitz, J. E. and Daniel, R. (2005). Enrichment of chitinolytic microorganisms: Isolation and characterization of a chitinase exhibiting antifungal activity against phytopathogenic fungi from a novel Streptomyces strain. Applied Microbiology and Biotechnology 66, 434-442.

Jain, P. K. and Jain, P. C. (2007). Isolation, characterization and antifungal activity of Streptomyces sampsonii GS1322. Indian Journal of Experimental Biology 45, 203-206.

Karimi, K., Amini, J., Harighi, B. and Bahramnejad, B. (2012). Evaluation of biocontrol potential of Pseudomonas and Bacillus spp. against Fusarium wilt of chickpea. Australian Journal of Crop Science 6(4), 695-703.

Kasana, R. C., Salwan, R., Dhar, H., Dutt, S. and Gulati, A. (2008). A rapid and easy method for the detection of microbial cellulases on agar plates using Gram's iodine. Current Microbiology 57, 503-507.

Katekan, D., Shannaphimon, W., Phichaya, T., Prapaporn, B., Arunee, A., Panupong, S. and Ekachai, C. (2009). Comparative study of proteolytic activity of protease-producing bacteria isolated from thua nao. Journal of Science and Technology 3(02), 269-276.

Kim, P. I. and Chung, K. C. (2004). Production of an antifungical protein for control of Colletotricum lagenarium by Bacillus amyloliquefaciens MET0908. FEMS Microbiology Letter 234, 177-183.

Liu, H., Jia, W., Zhang, J. and Pan Y. (2008). GC-MS and GC-olfactometry analysis of aroma compounds extracted from culture fluids of Antrodia camphorata. World Journal of Microbiology and Biotechnology 24, 1599-1602.

Mathur, A., Rawat, A., Bhatt, G., Baweja,S., Ahmad, F., Grover, A. and Dua, V. K. (2011). Isolation of Bacillus producing chitinase from soil: Production and purification of chito-oligosaccharides from chitin extracted from fresh water crustaceans and antimicrobial activity of chitinase. Recent Research in Science and Technology 3(11), 1-6.

Meijer, H. J. G., van de Vondervoort, P. J. I., Qing, Y. Y., de Koster, C. G., Klis, F. M., Govers, F. and de Groot, P. W. J. (2006). Identification of cell wallassociated proteins from Phytophthora ramorum. Molecular Plant-Microbe Interactions 19(12), 13481358.

Montealegre, J. R., Reyes, R., Perez, L. M., Herrera, R., Silva, P. and Besoain, X. (2003). Selection of bioantagonistic bacteria to be used in biological control of Rhizoctonia solani in tomato. Electronic Journal of Biotechnology 6, 115-127.

Nogórska, K., Bikowski, M. and Obuchowski, M. (2007). Multicellular behaviour and production of a wide variety of toxic substances support usage of Bacillus subtilis as a powerful biocontrol agent. Acta Biochimica Polonica 54, 495-508.

Saito, N. and Nei, M. (1987). The neighbor-joining method: A new method for reconstructing phylogenetic trees. Molecular Biology and Evolution 4, 406-425. 
Souto, G. I., Correa, O. S., Montecchia, M. S., Kerber, N. L., Pucheu, N. L., Bachur, M. and García, A. F. (2004). Genetic and functional characterization of a Bacillus sp. strain excreting surfactin and antifungal metabolites partially identified as iturin-like compounds. Journal of Applied Microbiology 97, 12471256.

Stockwell, V. O. and Stack, J. P. (2007). Using Pseudomonas spp. for integrated biological control. Phytopathology 97, 244-249.

Tamura, K., Peterson, D., Peterson, N., Stecher, G., Nei, M. and Kumar, S. (2011). MEGA5: Molecular evolutionary genetics analysis using maximum likelihood, evolutionary distance, and maximum parsimony methods. Molecular Biology and Evolution 28, 2731-2739.

Tariq, M., Yasmin, S. and Hafeez, F. Y. (2010). Biological control of potato black scurf by rhizosphere associated bacteria. Brazilian Journal of Microbiology 41, 439-451.

Usharani, T. R. and Gowda, T. K. S. (2011). Cloning of chitinase gene from Bacillus thuringiensis. Indian Journal of Biotechnology 10, 264-269.

Vanitha, S. and Ramjegathesh, R. (2014). Bio control potential of Pseudomonas fluorescens against coleus root rot disease. Plant Pathology and Microbiology 5, 216.

Vicedo, B., de la O Leyva, M., Flors, V., Finiti, I., del Amo, G., Walters D. and Gonzalez-Bosch, C. (2006). Control of the phytopathogen Botrytis cinereausing adipic acid monoethyl ester. Archives of Microbiology 184, 316-326.

Weiwei, L., Wei, M., Bingyu Z. and Feng, L. (2008). Antifungal activities and components of VOCs produced by Bacillus subtilis $\mathrm{G}_{8}$. Current Research in Bacteriology 1, 28-34.

Wheatley, R. E. (2002). The consequences of volatile organic compound mediated bacterial and fungal interactions. Antonie Van Leeuwenhoek 81, 357-364.

Yu-Hong, W., Li-Chuan, W., Wei-Chuan, C. and ShanYu, C. (2010). Production and characterization of fengycin by indigenous Bacillus subtilis F29-3 originating from a potato farm. International Journal of Molecular Sciences 11, 4526-4538. 